\title{
Drama ve İyi Oluş: Anlatı Kuramı ve Ruh Sağlığı Bilincini Arttırmada Interaktif Tiyatronun Kullanmi**
}

\author{
John Somers" \\ Exeter Üniversitesi \\ $\ddot{O}_{z e t}$
}

Bu makale yazartn Uygulamalı Drama uygulamastnın temelini oluşturan kuramsal ilkeleri incelemektedir. Bu uygulamalar arastnda terapi, anlat kuramt, özgüllük, kitle ön deneyimini doğrulama, kitlenin manevi kattltmı, gerçeğe uygunluk ve hedeflemeyle ilgili olan uygulamalar yer almaktadır. Uygulamall Drama'nın, genellikle metinlerarasilığa - bireyin kişisel kimliği olan öykü (metin) ile drama içinde deneyimlenen metnin etkileşim süreci - atfedilen tutum değişikliğini doğurabilmesine dair deliller sunulmaktadır. Yazar, dramanın genel olarak türdeş olan gruplara sunulmasina olanak taniyan "hedefleme" konusunu ele almaktadir. Bir Interaktif Tiyatro programinın nasıl araştırıldığı, geliştirildiği, sunulduğu ve değerlendirildiğine ilişkin bir açıklama verilmektedir. Ruh sağltğı konularını ele alan On the Edge [Sinırda] adındaki bir Interaktif Tiyatro'yla ilgili örnek bir vaka incelemesi sunulmaktadır. Bu programin değerlendirmesinin başlıca bulgulart verilmektedir. Yazarın vardığı sonuca göre, bu nitelikteki Interaktif Tiyatro, Uygulamalı Dramantn çok değerli bir çeşididir ve katılımclların deneyiminin doğrudan ömek materyal olarak kullanıldı̆̆ı tartışmalarda bulunması zor konuların ele alinmasina olanak tanir.

Anahtar sözcükler: Uygulamalt drama, drama, interaktif tiyatro

\section{Giriş}

Öncelikle, bu makalede bahsi geçen türdeki uygulamalanı etkileyen birtakım teorik, dramaturjik ve pratik meseleleri ele alacağım. Bu bölümün okuyucuyu, çalışmanın içine oturtulduğu felsefi bağlam konusunda bilgilendireceğini umuyorum. Sonrasında ise İnteraktif Tiyatro'ya ilişkin örnek bir vaka incelemesi aracılığıyla çalışmanın uygulamaya nasıl geçirildiğimi göstereceğim.

\section{Dramanun Terapotik Ctkisi}

Bazılan tüm drama deneyimlerinin terapotik etkisi olduğunu iddia etmektedir. Atölye çalışması başkanlarınm, öğretmenlerin ve eğitim ve toplum tiyatrosu şirketlerinin genel olarak çalışmalarının sonucunda iyiye yönelik bazı değişimlerin gerçekleşeceği beklentisi içinde olduklan düşünïliür. En azından 'iyi bir şey yapma' beklentileri vardir. Daha belirgin olarak, belirli drama etkinlikleri potansiyel olarak karmaşık psikolojik ve duygusal değişimlere - örneğin

\footnotetext{
** Bu makalenin İngilizce'den Türkçe'ye çevirisi Hermetika Ceviri Grubu tarafindan yapılmıştır.

*Prof. Dr., Exeter Üniversitesi, E-Posta: J.W.Somers@exeter.ac.uk
} 
dramaterapistlerin ve psikodramatistlerin çalışmalanna - ulaşmayı hedeflemektedir. Dramanın terapotik cetvelini şu şekilde görebiliriz:

\section{Psikodrama}

Dramaterapi

Performans Tiyatrosu

Sol tarafta açık bir terapotik niyet vardır. Bu çizginin sağ tarafında ise tiyatro; eğlence, zihin sakızı, polemik, propaganda, egemen öykülerin sözcüsü ve alternatif karşı-öykü olarak çok çeşitli şekillerde var olur.

Aradaki bölgede, özellikle de çizginin sol tarafındaki bölgede, değiştirmeye yönelik açık veya örtülü amaçlan olan geniş bir aralıktaki drama etkinlikleri yer almaktadır. Bu değişikliklerin çoğu terapotik olarak görülebilir. Bu bölgelerden biri, benim de ilgili olduğum Uygulamalı Drama alanıdır.

\section{Uygulamalı Drama}

Uygulamalı Drama basit bir şekilde şöyle tanımlanabilir: Drama etkinliğinin belirli bir toplumsal durumda genellikle önceden tasarlanmış bir değişikliği elde etmek için kullanımı. Bu nedenle Uygulamalı Drama zihinde belirli bir amaçla geliştirilir - yerine getirmesi gereken bir görevi vardır. 'Uygulamalı Tiyatro' yerine 'Uygulamalı Drama' terimi kullanıyorum çünkü bu makalede tartışılan örnek vaka incelemesi açıkça tiyatro öğelerini kullanmasına rağmen, diğer çalışmalarımın büyük kısmı performans temelli değildir. Bu nedenle daha kapsamlı bir terim olan 'drama' tiyatro alanlan ve performansıyla ilgili yersiz çağnışımlan (özellikle de sıradan insanların zihninde) önlemektedir. Bunun başka bir sanat türündeki benzeri, o sanat formunun birçok alt bölümlerinin terimleri yerine daha kapsamlı olan 'dans' terimini kullanmaktır.

Uygulamalı Drama, drama ve tiyatroda yetenekli olan ve psikoloji, pedagoji ve sosyoloji gibi alanlarda ilgili bilgi, beceri ve bilince sahip olan uygulayıcılar gerektirmektedir.

Çalışma süreci şu şekilde açıklanabilir:

- Drama müdahalesinin gerçekleşeceği bağlamın araştırılması;

- Bu bağlamda yer alan insanları anlama;

- Amaçların tanımlanması; 
- Katılımcı değişimi için en ideal koşullanı sağlamak üzere yapılandırılmıs bir drama deneyiminin oluşturulması;

- $\mathrm{Bu}$ deneyimin sunulmasi;

- Müdahalenin etkililiği konusunda karar vermek için sonuçlann değerlendirilmesi.

Tüm bunlar hedef kitle ile ve onlar tarafından oluşturulabilir ve genellikle böyle olur. Uygulamalı Drama, terapotik etki konusunda azami potansiyele sahiptir çünkü her bireysel koşul kümesi için özel olarak hazurlanmıştır ve yönetici ile katılımcılar, yönetmen ve oyuncular, çocuklar ve öğretmenler arasında bir işbirliği oluşturur.

\section{Anlatı Kuramı}

Dünyamıza ve onun içinde nerede bulunduğumuza ilişkin hissimize yalnızca öykü aracılığıyla erişilebilir. An içinde yaşıyoruz ve olup biten veya gelecekte olacak olan şeyler yalnızca öykü aracılığıyla anlatılabilir. Etrafımız öykülerle çevrili. Eğitimin büyük bir kısmında - en belirgin olarak edebiyat ve dramada fakat aym zamanda da, örneğin, tarih (tanım olarak gelmiş geçmiş olanla ilgilenmektedir) ve coğrafyada (günümüz modern toplumunda bile asla gidemeyeceğimiz yerler ve kültürler hakkında bizi bilgilendirmektedir) - öğretim vasıtası olarak öykü kullanılmaktadır. Öyküsüz kalmak, bizi bir geçmiş veya gelecekten, düşünme veya tahmin etme yeteneğinden mahrum bırakır. Öykünün uzaklaştırıcı etkisi, biz onları oluşları içinde tasarlarken bize olaylara dair bir bakış açısı kazandırır. Bir Alzheimer hastasının durumu, bize öykülere ulaşamamanın sınırlamalanna iliş̧kin bir örnek sunar.

\section{Özgüllük}

Etkili drama, tasvir ettiği koşullar bakımdan her zaman özgüldür. İnsanların durumlarına ilişkin detaylar üzerinde gelişir ve bu, katılımcılanı kendilerini insanlarla ve sorunlarıyla özdeşleştirmelerine yardımcı olur. Yalnuzca genellemelere maruz bir konuyla kişinin kendisini gerektiği gibi ilişkilendirmesi zordur. Örneğin, 'Açlık konusundaki fikirleriniz veya hisleriniz nedir?' diye bir soru sorulduğunda cevabımız şöyle olabilir: 'Duruma bağlı. İlgili kişiler çok mu açlık çekiyor; herhangi bir destek görmüyorlar ve ölme tehlikesiyle mi karşı karşıyalar? - örneğin dünyanun sosyal hizmetler bulunmayan münferit bir bölgesinde mahsul kıtlığı nedeniyle böyle bir durum mu yaşıyorlar, yoksa yalnızca unutkanlıktan dolayı öğle yemeğini mi yemediler ve o akșam yemeklerini büyük bir iştahla mı yiyecekler?' Drama insana ve bağlama ilişkin ayrıntılan oluşturmamıza, genellemelerden kaçınmamıza imkan tanır ve bu, insanlarla ilişki kurma yeteneğinin altında yatan sırdır. 


\section{Doğrulama}

Uygulamalt Drama çalışmasının en önemli rollerinden biri insanlann deneyimlerine ilişkin bir tür doğrulama hissi yaratmaktır. İyi oluş halinde sorunlar olan birçok insan içinde bulunduğu durumdan utanır ve yaşadığı sorunları anlamayacaklarını düşündüğü kişilerle paylaşmak istemez. İzleyenlerin hayatlanna ilişkin bir durumu yakalayabilmiş bir drama grubunun ortaya koyduğu bir öyküye şahit olmanın oldukça olumlu bir yönü olabilir. Bunun etkili olması için, izleyicinin öykünün konusunun ve içinde bulunan karakterlerin kendi deneyimlerine ilişkin gerçeklikleri yansıttı̆gmı hissetmesi gerekmektedir.

\section{Manevi açıdan dahil edilen izleyiciler}

Avrupa tiyatrolanının büyük kısmı hala ışıklandırılmış bir sahnenin olduğu karanlık bir salonda oynanmaktadır. Bu durum, oyuncular ve izleyiciler arasında katı bir sınırlama olduğunu ve izleyicilerin konuşmamasını veya sahnedeki oyunla açık bir şekilde etkileşime girmemesinin beklendiğini akla getirmektedir. Bu tür tiyatroyla ilgili adetler anlaşlmakta ve genellikle bunlara bağlı kalınmaktadır. Interaktif Tiyatronun doğası, izleyicilerin öyküyle ve karakterlerle ilişki kurmasını beklemesi ve desteklemesi açısından farklıdır. Bu yüzden izleyici ile oyun alanı arasındaki ayrım kasten belirsiz bir hale getirilmiştir ve 1şı veya fiziksel engellerle sınurlanmamıştır. İzleyici gösteriyi izlemeye genellikle öykü ve bazı karakterlere ilişkin önbilgi ve hayatlarında neler olup bittiğine ilişkin birtakım varsayımlara sahip olarak gelecektir. Bu teknik, kişisel ve resmi materyallerin ve izleyicilerin öyküye genellikle iki soruyla oluşturulan varsayımlar aracılı̆̆ıla yönlendirilmesine yardımcı olan yazılı belgelerin kullanımını gerektirir. Bu iki soru: 'Öyküdeki insanlar kimdir?' ve 'Başlarına ne geliyor?'dur. Bu kaynağa 'birleşik uyaran' adını vermekteyim.

\section{Gerçeğe Uygunluk}

Hedef izleyici kitle oyunun gerçeğe uygun olmadığı yargısına varması durumunda oyun başarısız olacaktır. 'The Living at Hurford' [Hurford'da Yaşam] adındaki İnteraktif Tiyatro programı, 2002 yılında ayak ve ağız hastalığının patlak vermesinin ardından küçük aile çiftliklerinin piyasada kalma mücadelesini ele almıştur. Benim yazdığım bir tiyatro olan 'The Living at Hurford' [Hurford'da Yaşam] devlet tiyatrocuları tarafindan bu hastalığın yaşandığı bir çiftliğin ahırında sahnelenmiştir. Program sona erdikten sonra hemen yanıma gelen bir çiftçi omzuma dokunarak bana şöyle demişti: 'Çiftçilikle ilgili ne bildiğini bilmiyorum oğlum, ama yazdıklann gerçek'. Çiftçilerle de konuştuğum uzun süreli araştırma sürecim, onun dünyasını yansıttığını hissettiği bir şeyi ortaya koymuştu. Bir başka performansın ardından başka bir çiftçi: 'Bu gece sahneye koyduğunuz benim hayatımdı,' dedi. Hedef kitle öykünün yaşanmış gerçekliği 
yakaladığını düşünmediği sürece, vasıtanın değişimi doğurma ve doğrulamayı gerçekleştirme gücü zayıflayacaktır.

\section{Davranış Değişikliği}

Araştırmalar Uygulamalı Drama ve Tiyatroya dahil olmanın tutum ve davranış değiştirmenin en etkili yolu olduğunu göstermektediri. Örneğin, James Catterall'ın yayınlanmış bir araştırmasının meta-analizi şu sonuca varmıştur:

Drama sosyal ilişkileri, karmaşık sorunlan ve duygulanı anlamaya yardımcı olur; düşünceyi yoğunlaştırmayı ve öykü anlamayı geliştirir.

1980'lerde yaptı̆̆ım, Birleşik Krallık'm farklı yerlerinde bulunan 35 okulda gerçekleștirilmiş bir araştırma, öğrencilerin planlanmıs drama dersleri almanın bir sonucu olarak engelli olmaya karşı olumlu davranış değişikliği gösterdiğini ortaya koymuşturii. Drama deneyiminin bunu yapabilme gücünün, insanlara ilişkin durumların ayrıntılarına dayanan gerçekçi kurgular sağlamasından geldiğine inanıorum.

\section{Hedefleme}

Genellikle izleyiciler arasında bir türdeşlik sağlamanın mümkïn olmadığı alışılmış tiyatro deneyiminin aksine, Uygulamalı Tiyatroda uygulayıcular genellikle hedef izleyici grubunun/atölye katılımcılarının oluşumu hakkında bilgi sahibidir. Bu durum uygulayıcıların, katılanları ilgilendirecek bir drama deneyimi yaratmasına olanak tanımaktadır. Bu, hedef katılımcılar arasında çeşitliliği engellemez; örneğin yakın zamanda gerçekleştirilen veterinerlik mesleğini ele alan bir projede izleyiciler arasında beş yıllık okulun her sınıfından veterinerlik öğrencileri, veteriner cerrahlar, araştırmacılar, görev yapan ve emekli olmuş veterinerler, danışman, terapistler ve mesleğin yönetim kademesinde bulunan kişiler yer alıyordu. Hepsinde ortak olan özellik ise mesleğe dair bilgi - veya öğrencilerde artan bir bilinç - ve mesleğin mensuplannda oluşturabileceği baskılardı.

\section{Metinlerarasilk}

Dramanın davranış değiştirme gücü, metinlerarasılık kavramında, öykülerin dinamik ilişkisinde yatmaktadır. Bu durumda metinlerarasılık, sahneye koyulan öykünün bireyin kişisel kimliğini oluşturan öyküyle iç içe girmesidir. David Novitz ${ }^{\text {iii }}$ hayatlarımızda gerçekleşen olayları sürekli olarak seçip düzenleme süreci aracılı̆̆ıyla öz kimliğimizin bir öyküsünü yarattığımızı varsaymaktadır. Önemli olay ve öykülerin algılanan kimliğimizde değişiklikler yaratma gücü vardır. Bir drama deneyimi de bunu yapabilir fakat bu yalnızca 'kim olduğumuz'la güçlü bir 
bağlantı kurması durumunda gerçekleşir. Bunun atölye koşullarında gerçekleştirebileceğine inansam da, bu makalede bana aynlan kusımda İnteraktif Tiyatro'ya odaklanmayı tercih ediyorum.

\section{İnteraktif Bir Tiyatro Programı Nasıl Araştırılır, Geliştirilir, Sunulur ve Değerlendirilir?}

İzleyici için önem arz eden gerçekçi bir biçimde sahnelenen bir öykü elde etmek için, söz konusu konuların bu sahnelemeyi gerçekleştirecek kişiler tarafından mümkün olduğunca iyi bir şekilde anlaşılması gerekmektedir. Konuya ilişkin bir araştırma sürecine girmek ve öykünün devamını sağ́layacak olan drama formunu tecrübe etmek gerekmektedir. Program üzerine çalışan kişilerin, - deneyim ve/veya eğitim aracılığıyla - bu konuya ilişkin uzman bilgisine sahip olan kişilere erişiminin olması çok önemlidir. $\mathrm{Bu}$ danışma grubu, yaratılan programın gerekli gerçekçilik özelliklerine sahip olmasını sağlayabilir.

Program, ${ }^{\text {iv }}$ araştırma veya düzenleme süreciyle oluşturulmuş bir senaryodan geliştirilebilir. Düzenleme süreci açık ve serbest olabilir fakat zaman kısıtlamaları ve birtakım üretici kısıtlamalan sağlama ihtiyacı göz önüne alındığında, ben genellikle senaryoyu, diyalog parçalarını ve dramatik forma ilişkin genel bir anlayışı kapsayan bir 'iskelet' oluştururum. Gelişim süreci nasıl olursa olsun, oyuncuların konuyu derinlemesine araştarması gerekmektedir. Genellikle provama/gelişim sürecime, iki veya üç oyuncunun yaptığı araştırmanın sonuçların bir araya getirerek başlanm. Bu şekilde, oyuncular projeyi anlamakta ve sahiplenebilmektedir.

Programın sunumunun ilk basamağı genellikle izleyicinin, benim 'birleşik uyaran' adını verdiğim bir araç vasıtasıyla konulara ve öyküye yönlendirilmesinden oluşmaktadur. Bu, birçok öğeyi içermesi bakamından 'birleşik' ve öykü oluşturmayı teşvik etmesi bakımından bir 'uyaran'dır. Bu çalışmanın büyük kısm, yalnızca izleyici sayısım yaklaşık 40 ile sınırlandırarak elde edilebilecek bir samimiyet gerektirmektedir. Bu, izleyicilerin öykünün konusuna, karakterlere ve onlan etkileyen sorunlara dahil olmasına yönelik fırsatları ideal hale getirir. Aynca tüm interaktif çalışmanın da kontrol edilebilir olmasını sağlar. İzleyicinin karakterlerle tanıştığı, sorunla kendini özdeşleştirdiği veya sonunu 'hissettiği', karakterlerin sonuca ulaşmadan önce sorunla boğuştuğunu gördüğü iyi kurulu bir oyunun aksine, İnteraktif Tiyatro genellikle oyunun sahnelenmesini kriz anında durdurur. $O$ anda bir yönetici ${ }^{\vee}$ araya girer ve izleyicileri karakterlerin yaşadığı sorunlan daha iyi anlamaya ve öyküye devam edebilecekleri üretken yollara ilişkin öneriler sunmaya davet eder. Şimdi bu özellikteki bir projeyi anlatacağım.

\section{On the Edge [Smrrda]}

Burada Uygulamalı Dramanın 'görev'i üçtür:

- Ruh sağlığı bilincini artırmak ve özellikle psikoza ilişkin bilgi ve anlayışı artırmak; 
- Ruh sağlı̆ı̆na ilişkin damgalama ve ayrımcilğı azaltmaya katkıda bulunmak;

- Mevcut yardımlara ilişkin bilinci artırmak ve yardım aramaya yönelik davranı̧̧ı geliştirmek.

Hazırlık araştırması altı aylık bir süre boyunca sürdürülmüş̧̦̈̈r ve kişisel olarak ruh hastalı̆ı deneyimi yaşamıs olan kişilerden, ruh hastalığı uzmanlarından, bir sanat terapistinden, ruh hastahğı kuruluşlannın temsilcileri ve bakıcılardan oluşan ve kendini bu konuya adamış bir Danışma Grubunun yönlendirmesinden yararlanılmıştır. Bu grup aynca tüm gelişim süreci konusunda önerilerde bulunmuş ve ilk performanslara katılarak geribildirim sunmuştur. Program, Exeter Üniversitesi Drama Departmanı Üçüncü Sımf öğrencileri tarafindan 2003/4 akademik yılının ilk sömestrinde, Uygulamah Dramanın bir modülü olarak geliştirilıniştir. Bu grup program, okullarda, kolej ve üniversitelerdeki on altı yaş üstü izleyicilere ve konferanslar aracılığxyla ruh sağhı̆̆ı uzmanlanna taşımıștır Akabinde program, Sanat Yönetmenliğini yaptı̆ı̆m tiyatro şirketi Exstream tarafından satın alınmıştır. Proje, Wellcome Vakfı ve başka fonverenlerden 148 bin sterlinlik fon sağlamış ve ulus çapında bir tura çıkmıştur ${ }^{\text {vi }}$. Yenilikçi uygulaması için Southern Region Department of Health Award ve National Institute of Mental Health England, National Positive Practice Award ödüllerini almıştur. Programın amaçlarına ulaşma konusundaki etkililiğine ilişkin kapsamlı ve bağımsız bir araştırma raporu oluşturulmuştur.

Modülün başlangıcından önce ve Damşma Grubuyla modül öncesi toplantılarımın son aşamalannnda, bir senaryo yazarak sahne yapısına ve diyalog parçalarına ilişkin öneriler sundum. Danışma Grubu bunu tartışmaya aldı ve değişikliklerden sonra özgül olduğu kararına varıldı. $\mathrm{Bu}$, öğrencilerin tüm performans öğesini geliştirmesi amacıyla düzenleme sürecine başlaması için başlangı̧ noktası oluşturdu. Grup üyeleri birleşik uyaranın, veri tasanmlı görsellerin, ses efektlerinin, müziğin, tanıtımın ve devam paketinin hazırlanması da dahil olmak üzere diğer tüm görevleri onların arasında paylaş̧ırd.

\section{Öykünün Konusu}

Birleşik uyaran on dört öğeden oluşmaktaydr. Uyaran bir ayakkabı kutusuna konmuştu. On altı yaş üstü grupla çalışan kişilerden, Exstream gelmeden önceki hafta içinde kutunun içerik ve anlamım araşturmaları istendi.

Öğeler: bir okulun Terry Gardner'ın A Seviyesindeki çalışmalarındaki düşen standartlar karşısında hayal kırıklığını ifade eden bir mektup; onbeş yaşlarındaki bir kızın fotoğrafı, yaşlıca bir kadının fotoğrafi, onbeş yaşlarındaki bir erkek çocuğun bir erkek arkadaşıyla çekilmiş bir 
fotoğrafi; Terry Gardner adına yerel bir müsabakada alınan bir kupa, büyükannesinin Terry'ye yazdığı bir doğum günï kartı; bir şişe TCP ${ }^{\text {vii }}$ ve hidrofil pamuk; Darren Campbell adındaki bir İngiliz Olimpik koşucusunun Terry'ye yazdığı ve antrenmanlarına devam etmesi konusunda 1srar ettiği bir mektup; bir kızdan özel bir not; 16 yaşında GCSE sınavından aldığı iyi sonucu kutlamak üzere ‘Anne ve Baha'sının Terry'ye yazdığı bir tebrik kartı.

Yukarıda özetlendiği şekilde olan birleşik uyaran, Exstream gelmeden önceki hafta içinde öğretmen tarafından kullanılmıştır. Öğretmen uyaranı kullanmadan önce, kutunun gelecek hafta bir tiyatro şirketinin sahneleyeceği kurgusal bir oyunun bir parçası olduğunu bildirmiştir. Katılımcılara bu kutunun bir erkek çocuğunun yatağının altında bulunduğu söylenmiştir. Her nesne bireysel katılımcılar tarafından sırayla çıkarılmış ve her birinin diğer materyallere göre önemi incelenmiştir. Bu süreç 30 dakika sürecek şekilde ayarlanmıştır

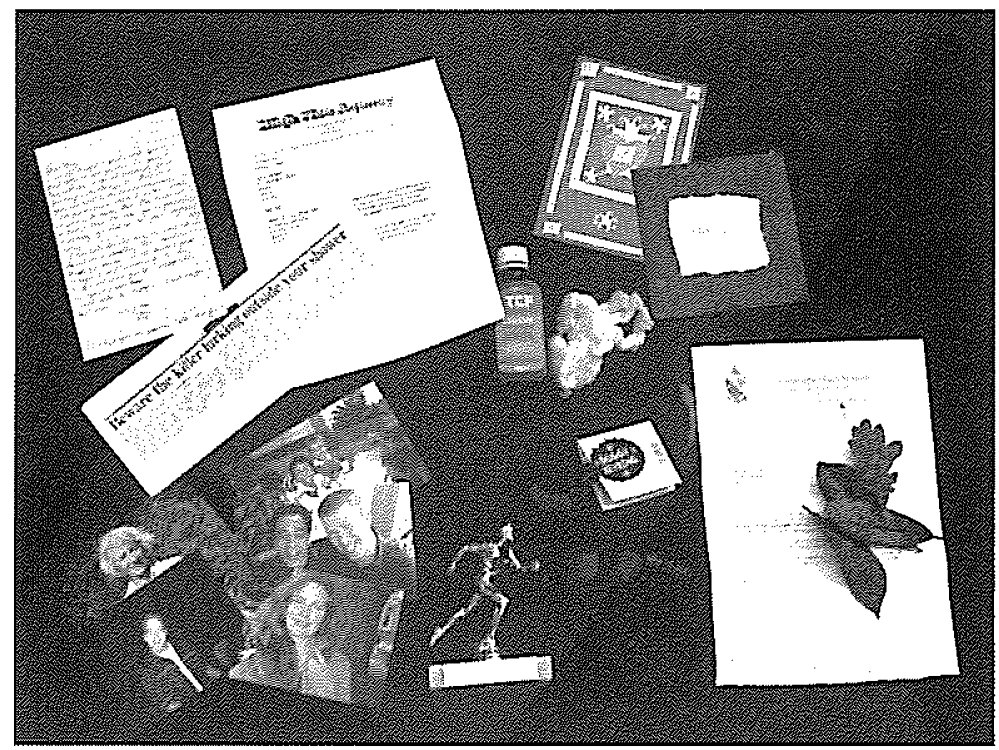

Birleşik uyaran

ve sonunda katılımcılar karakterlerin hayatlanna ilişkin eksik fakat ilgi çekici bir bakış açısı kazanmıştır.

Performans öğesi 50 dakika sürmüştür ${ }^{\text {viii }}$. Terry Gardner'ın mutlu bir çocukluktan, hem akademik hem de atletik açıdan başarıdan, psikozun ilk epizodunu yaşadığı noktaya kadar ilerleyen gelişimini takip etmiştir. Birleşik uyarıcmın içeriği performans öğesine dahil edilmiştir ve ayakkabı kutusu Terry'nin yatağının altında görülebilmektedir. 
Özetle oyundaki etmenler, babasının Terry'ye atletik yeteneklerini geliştirmesi için antrenman yaptırması ve Terry'nin bir sorunu olduğunu bir türlü kabul etmemesi; Terry'nin adım adım bir psikoz durumuna girmesi (yakın zamanda ölen büyükannesinin yaralarına kompres yaparken kullandığı TCP, Terry için sihirli bir sıvı haline gelmiştir ve bununla kendini uyuşturmaktadır); Terry'nin annesinin, kocasını uzaklaştırmak istemediği için oğluyla gerektiği gibi ilgilenememesi; okul arkadaşlarının Terry'yi aşağılaması - Terry'nin gitgide dengesizleşen davranışlarını tanımlamak için 'psikopat' ve 'kaçık' gibi sözcükler kullanmaktadırlar; Terry'nin değişen durumunu en çok anlayan ve ona yardım etme konusunda istekli olan fakat nasıl yardım

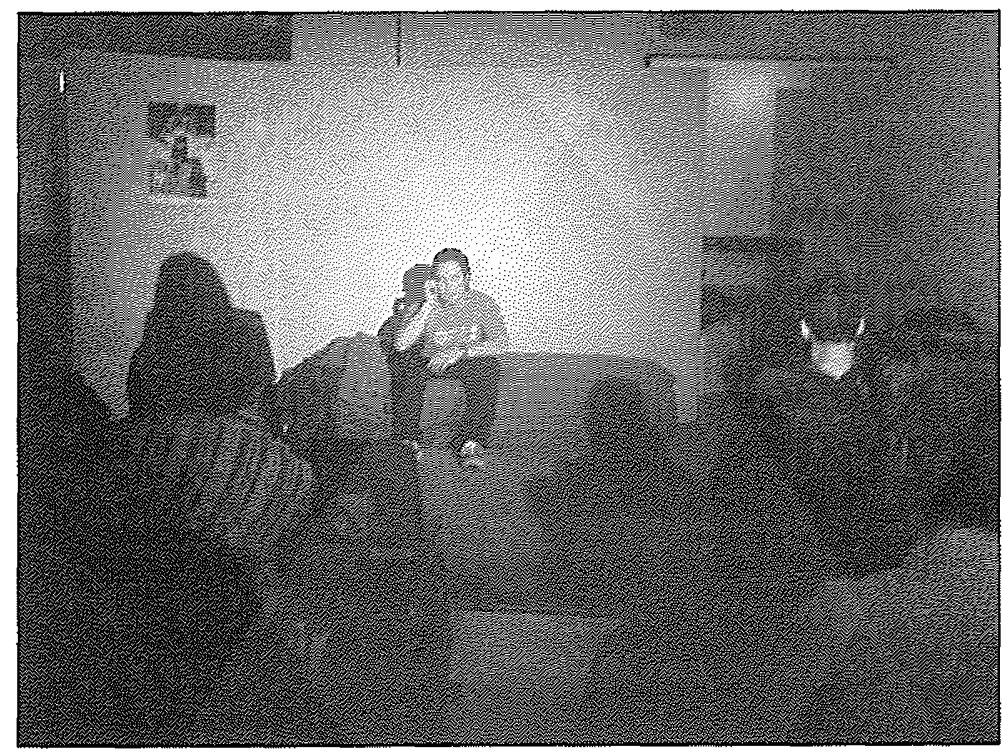

Terry ölen büyükannesine telefon eder

edeceğini bilemeyen sadık kız arkadaşı Sonia'nın artan şaşkınlığı; okulun Terry'ye ne olduğunu anlayamaması; Terry'nin ölen büyükannesini telefonla araması.

Performans öğesi kriz noktasıyla sona erer; bu noktada Terry yatak odasında yaşayan bakterileri görür, Darren Campbell'ın resminin parladığım ve nabzımn attığını düşünür ve Sonia'yı korumak için ona bağınr ve odasından atar. Sonia merdivenlerde Terry'nin annesiyle karşılaşır ve birbirilerine sarllılar; annesi sonunda sorunla yüz yüze gelir.

Yönetici (altı ay süren tur boyunca bu görevi, Devon Partnership NHS Trust'in desteğiyle görevlendirilen bir psikiyatri hemşiresi yerine getirmiştir) sahneye çıkmış ve izleyicilerden yanındakilerle Terry'ye ve etrafındaki kişilere ne olduğunu tartışmasını istemiştir. Sonra izleyicilerden karakterlerin his ve isteklerini daha iyi anlayabilmeleri için konuşmak istedikleri (sıcak koltuktaki) karakterleri seçmesi istenmiştir. Bundan sonrası izleyici grubuna bağlı olarak 
değişiklik göstermiştir. Bazen izleyiciler gruplara ayrılmış ve karakterin öykü içindeki tepkilerini tartışmak üzere bir oyuncuyla çalışmıştır. Bazense izleyicilerden öyküyü olumlu bir şekilde sürdürecek bir sahne üzerinde karar kılmalan istenmiştir ve oyuncular bu sahneyi oynamıştır. Çoğunlukla izleyicilerden karakterlere durumu iyileştirmeye yönelik öğütler vermesi istenmiştir.

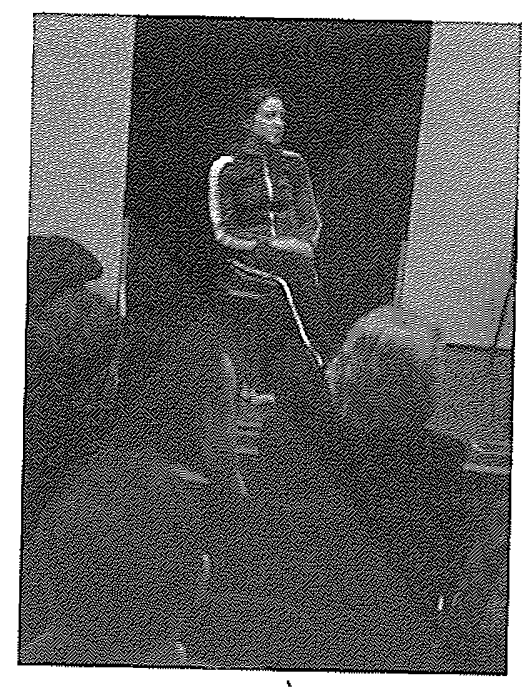

Sonia sicak koltukta

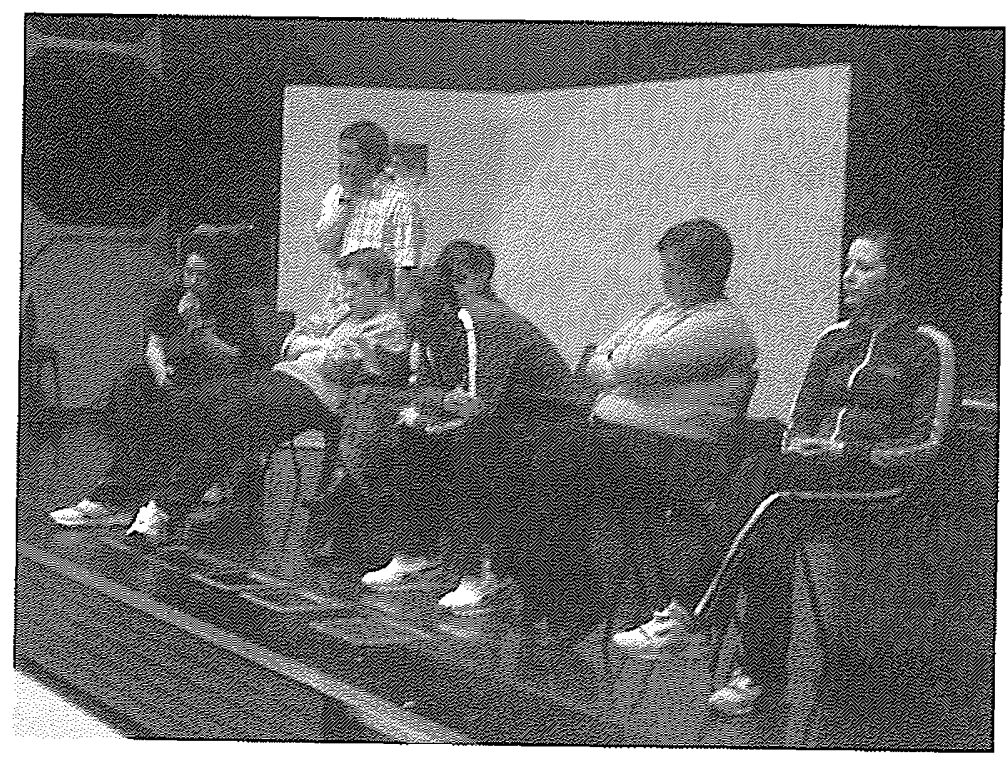

İzleyiciler karakterlere öğüt verir 
Bir tür kapanış gerçekleştirmek için iki saatlik sürenin son 10 dakikasında yönetici slaytlar eşliğinde Terry'nin iyileşmek için yönelebileceği yolları sunmuştur. Her duruma, devam ederek izleyicilerin anlayışını derinleştirmek için belirli sürelere bağlı kalınarak karmaşıklıkta kullanılabilecek çok yönlü bir devam paketi olan 'Back From the Edge' [Sınırdan Dönüş] verilmiştirix $^{\text {ix }}$ Program için rezervasyon yaptıran kişi, Exstream'in gelişinden sonraki hafta içinde devam paketini kullanmayı vaat etmiştir. Performanslar, Erken Müdahale görevlilerine ${ }^{x}$ bildirilmiş ve katılımların sonunda her bir durumdaki personel ile aralarında kalıcı bağlar oluşması beklenmiştir.

\section{Araşturma/değerlendirme ${ }^{\mathrm{xi}}$}

Programın sonuçlarını amaçlarına ilişkin olarak değerlendirmenin gerekli olduğuna inanıyorum. Böyle bir değerlendirme, program sonrası bir anket gibi basit bir biçimde gerçekleştirilebilir veya daha karmaşık nitel ve nicel araşturma araçlarını da içerebilir. 'On the Edge' [Sumrda] ikinci tip değerlendirmeye tabi tutulmuştur ve buna seçilen katılımcılarla altı ay sonra gerçekleştirilen bir takip görüşmesi de dahildir.

\section{Başlica Bulgular ${ }^{\text {xii }}$}

1. Veriler, programın tamamlanmasının ardından öğrencilerin psikoza ilişkin bilincinin ve bilgisinin arttuğın göstermiştir. Öğrenciler, öğretmenler ve ruh sağlı̆̆1 uzmanlan bu konuyu önemli görmektedir ve katılımcıların neredeyse hepsi programın psikoza ilişkin bilinci etkin bir şekilde arturdığına inanmaktadır.

2. Program damgalamaya birçok farklı şekilde karşı çıkmaktadır.

3. Öğrenciler programa katıldıktan sonra yardım alma konusunda daha donanımlı görünmektedir.

4. On the Edge [Sınurda] birçok öğxenci, öğretmen ve ruh sağlı̆ı uzmanı tarafından yüksek kalitede bir TIE (Theatre in Education-Eğitimde Tiyatro) programı olarak kabul edilmiştir. Programın temel avantajlan gerçekçi olması, izleyiciler dahil edebilmesi ve ruh sağlığı sorunların inceleme konusunda verdiği güven duygusudur.

5. Program sokaklarda satılan uyuşturucular ve psikotik deneyimi anlamak gibi karmaşık ve tartışmalı konulara kısaca değinmektedir. Bu iki konuya dair az miktardaki geribildirim, genel eğitimsel mesajın açı ve odaklanmış olduğunu göstermektedir.

6. Programın ayakkabı kutusunu içeren iki saatlik bir oturum şeklinde gerçekleşen formatı başarılı olmuştur çünkü katılımcılan karakterlerin hayatlarına dahil olma konusunda teşvik etmiş ve bilgiyi farklı öğrenme türlerini tatmin edecek biçimlerde sunmuştur. Oyun, programın en 
akılda kalıcı kısmı olarak görülmüş ve bu konulan betimleme konusunda ilgi çekici ve güçlü bir yol olarak önemli destek görmüştür.

7. Tüm okullar bu eğitsel desteği sağlayacaklarına dair 'vaatte bulunmalan'na rağmen, bazılan programın üçüncü kısmına vakit ayıramamıștır.

8. Back From the Edge' [Sınırdan Dönüş] adındaki eğitim paketi çeşitli tepkiler görmüştür; bazı öğretmenler istekliyken diğerleri bu bilgilere erişmenin kolay olmadığını düșünmüștür. Materyalleri okuma ve üzerinde düşünmek için yeterli zaman olmamasının bu tepkiye etkisi olmuştur.

\section{Sonuç}

Bu proje, büyük hedeflerle yola çıkan karmaşık bir projeydi. Araştırma sonuçlan bu hedeflerden birçoğuna ulaşıldığını göstermekte ve bu İnteraktif Tiyatro programının çok hassas bir konuyu ele almak için etkili bir yol olduğuna dair güçlü kanttlar sunmaktadır. Tur süresince on iki izleyici psikiyatrik hemşireye açılmış veya yardım almak için yerel EM görevlilerine başvurmuştur. Şirketin ziyaretinin ardından, iki saatlik ziyaretin sonunda her izleyiciye sunulmuş olan bilginin hızlandırdığı başka birçok konsültasyonun gerçekleşmiş olması muhtemeldir.

$\mathrm{Bu}$ nitelikteki Uygulamalı Dramanın, özellikle katılımcıların deneyiminin doğrudan örnek materyal olarak kullanıldığı tartışmalarda bulunması zor konulanın güçlü ve gerçekçi bir şekilde ele alınmasına olanak tanıması açısından iyi oluşu desteklemek için önemli bir öğe olduğunu iddia ediyorum.

(Bu makale yayınlanmış bir kitaba dayanarak yazılmıştur: Dramatherapy and Social Theatre [Dramaterapi ve Sosyal Tiyatro] (2008), Sue Jennings (Ed) Londra: Routledge.)

\footnotetext{
i Bkz. Taskforce on Underage Alcohol Misuse [Reşitlikten Önce Alkol İstisman Calı̧̧ma Kolu], Kate Fox (1997), Londra: The Portman Group, s.27.

ii Bkz. Somers, J., (Ed), (1996) 'The Nature of Learning in Drama in Education'[Eğitimde Dramayla Ögrrenimin Doğası], Drama and Theatre in Education: contemporary research, [Eğitimde Drama ve Tiyatro: Güncel Araştırmalar] Captus Press, North York, Kanada, s. 107-120 yer alan makalem.

iii Novitz, D. (1997). Art, Narrative and Human Nature' [Sanat, Öykü ve İnsan Doğası], Hinchman L. \& Hinchman, S. (Ed.) Memory, Identity, Community, [Hafiza, Kimlik ve Toplum] New York, State University of New York.

iv Program terimini kullanıyorum çünkü 'eser', 'oyun' veya 'gösteri' terimleri, bu gibi bir çalışmanın zorunlu kıldı̌̆ teatral, sanatsal, sosyolojik ve pedagojik yapı dizisini layıkayla ifade etmemektedir. Sahnelenen öyküyü (öğelerden yalnızca biri) 'performans öğesi' olarak anmaktayım.

v Yönetici izleyici ile öykü arasında bir köprü vazifesi görür. Yöneticiler, izleyicilerin karakterlerle etkileşim içine gireceği yollar işaret edip destekleyebilir.

vi Sirket Ekim 2004 ila Mart 2005 arasında süren ulus çapında bir tura çıktı ve 123 izleyici kitlesine - bunların 79'u hedef kitlenin 14 ile 22 yaşlan arasında olduğu 54 okul, kolej ve üniversitedeydi - oyunlar sergiledi. Bunlann kurk
} 
dördü, programin devam eden profesyonel gelişimin (CPD) bir parçası olarak kullanıldığı öğretmenler ve ruh sağlığı uzmanlan için gerçekleştirilen performanslar ve o dönemde Ingiltere'de yeni başlayan Psikoz servislerindeki yeni Erken Müdahaleyi (EM) desteklemek üzere yapılan konferans sunumlandır.

vii TCP ufak yaralanmalar için hanelerde sıklıkla kullanıllan antiseptik bir losyondor.

viii Birleşik uyaran ve devam hariç, tüm program iki saat gerektirmektedir.

${ }^{i x} \mathrm{Bu}$, programın gelişiminde yardımeı olan danışman psikiyatr Dr. Glenn Roberts tarafindan hazırlanmıştur. Programın ardından paket NIMHE (İngiltere Ulusal Ruh sağlığı Enstitüsü) tarafından ulus çapında kullanılmıştır.

${ }^{x}$ EM görevlileri Íngiltere'nin her yerine tayin edilmektedir. Bir İsveç araştırması, müdahale ne kadar erken olursa, hastanın iyileşmesinin o kadar hızlı olacağını göstermektedir.

xi Araştırma hem nitel hem de nicel yöntemler kullanmıştır:

- okullar, kolejler ve üniversitelerde öğrenciler için performans öncesi ve sonrası anketler (29 kurumdan edinilmiştir; tüm kurumlar araştırmanın iki kısmın da tamamlamamuşı̆ı).

- öğrencilerin katılmadı̆̆ performanslara katılan kişilerden alınan değerlendirme formlan ( $S=474)$.

- öğrenci, öğretmen ve öğrencilerin katılmadı̆̆ performanslara katılan kişilerle yapılan görüşmeler (133 öğrenci, öğretmen ve ruh sağ lğıl uzmanıyla gerçekleş̧irilen 72 görüş̧me).

- izleyiciler arasındaki sayı ve cinsiyet dengesin, sıcak koltukta sorulan soru türlerini veya iki saatlik oturumda meydana gelen herhangi bir ilgi çekici veya olağandışı olayı kaydeden oyuncu araștırma günlükleri.

xii Başlica Bulgular, Dr Rowena Passy (baş araştırmacı ve yazar) ve Dr Jos Dawe tarafından hazırlanan son değerlendirme raponunun içinde bulunan İdari özetten kısaltılarak alınmıştır. Raporun tamamı Exstream'in internet sitesinde 2007 yilında sunulacaktır. 


\title{
Drama and Well-Being: Narrative Theory and the Use of Interactive Theatre in Raising Mental Health Awareness.
}

\author{
John Somers* \\ Universty of Exeter
}

\begin{abstract}
This article explores the theoretical principles which underpin the author's Applied Drama practice, including those related to therapy, narrative theory, specificity, validation of audience pre-experience, the moral involvement of the audience, authenticity and targeting. Evidence is presented of Applied Drama's ability to bring about attitude change which is mainly attributed to intertextuality - the process by which the story (text) which is the individual's personal identity and the text experienced within the drama interact. The author deals with the issue of 'targeting' which allows delivery of the drama to generally homogenous groups. An explanation $s$ given of how an Interactive Theatre programme is researched, developed, delivered and evaluated. A case study is provided of an Interactive Theatre programme, On the Edge, which deals with mental health issues. The key findings of an evaluation of this programme are presented. The author concludes that Interactive Theatre of this nature is an invaluable form of Applied Drama, allowing a consideration of issues which are difficult to root (in discussion which directly uses participants' experience as illustrative material.
\end{abstract}

Keywords: Applied drama, drama, interactive theatre

\section{Introduction}

I will deal first with a number of theoretical, dramaturgical and practical issues which impinge on the kind of practice I am discussing in this article. I hope that this section will inform the reader of the philosophical context in which the work is set. I will then show, through an Interactive Theatre case study, how this is applied in practice.

\section{Drama's Therapeutic Role}

Some claim that all dramatic experience is therapeutic. It is axiomatic that workshop leaders, teachers and educational and community theatre companies generally expect that some change for the better will take place as a result of their work. At the very least, there is an expectation of 'doing good.' More specifically, certain drama activities aim at achieving potentially complex psychological and emotional shifts - the work of dramatherapists and psychodramatists, for example. We can see the therapeutic scale of drama in the following manner:

\footnotetext{
•Prof. Dr., University of Exeter, E-mail: J.W.Somers@exeter.ac.uk
} 
Psychodrama

Dramatherapy

Performance

Theatre

At the left there is explicit therapeutic intent. Theatre at the right of this continuum exists variously as entertainment, mental chewing gum, polemic, propaganda, as a mouthpiece for dominant stories and as alternative, counter story.

The area in between, especially on the left of the continuum is inhabited by a great range of drama activity that has explicit or implicit aims to change. Many of these changes could be seen as therapeutic. One such area is Applied Drama in which I am involved.

\section{Applied Drama}

Applied Drama can be defined simply as: The use of dramatic activity to achieve, often premeditated, change in a given societal circumstance. Applied Drama, therefore, is developed with a particular aim in mind - it has a job to do. I use the term 'Applied Drama' rather than 'Applied Theatre' as, although the case-study discussed in this article plainly uses theatre elements, much of my other work is not performance based. Thus the more generic term 'drama' avoids its unwarranted association (particularly in the lay mind) with theatre spaces and performance. The parallel in another art form would be the generic term 'dance' rather than using any of the multiple sub-sections of that art form.

Applied Drama requires practitioners who are skilled in drama and theatre, and who have relevant knowledge, skills and awareness in areas such as psychology, pedagogy and sociology.

The working process can be typified as follows:

- Research of the context in which the drama intervention will take place;

- An understanding of the humans who inhabit it;

- The definition of aims;

- The construction of a dramatic experience that is structured to provide optimum conditions for participant change;

- The delivery of that experience;

- Evaluation of the outcomes to judge the effectiveness of the intervention. 
All of this may be - and often is - created with and by the target group. Applied Drama has the maximum potential for therapeutic affect, as it is custom made for each individual set of circumstances and constitutes a collaboration between facilitator and participants, director and actors, children and teachers.

\section{Narrative Theory}

Our world and our sense of our place in it are only accessible through story. We live in the instant and anything which has passed, or is in the future, can only be represented through story. We are surrounded by stories. Large proportions of education use story as the vehicle for learning - most obviously in literature and drama, but also, for example, in history (which, by definition deals with that which has passed) and geography (to inform us of the places and cultures which, even in our modern, mobile society, we may never visit). To be denied story is to deny ourselves a past or a future, the ability to reflect or surmise. The distancing effect of story gives us a perspective on events as we model them outside the immediacy of their happening. The plight of the Alzheimer's sufferer gives us an example of the limitations of not being able to access stories.

\section{Specificity}

Effective drama is always specific in the circumstances it portrays. It thrives on the detail of human circumstance and this helps participants identify with the people and their issues. It is difficult to gain any proper engagement with an issue if it is only subject to generalities. If we are asked, for example, 'What do you think or feel about hunger?' the response might be 'It depends. Are the people involved so hungry and without support that they are in danger of dying - through crop failure, for instance in an isolated area of the globe without social services, or did they simply miss lunch due to an oversight, and will eat heartily that evening?' Drama allows us to create that human and contextual detail, to avoid generalisations, and this is the secret of its ability to engage people.

\section{Validation}

One of the crucial roles for Applied Drama work is to create a sense of validation of people's experiences. Many people who have defective well-being are embarrassed at their condition and do not wish to share the issues they are experiencing with those they feel may not understand. There can be something quite positive in witnessing the story created by a group of drama workers who have taken the trouble to capture aspects of a life circumstance of audience 
members. For this to be effective, the latter need to feel that the storyline and the characters within it reflect the verities of their own experience.

\section{Morally Implicated Audience}

Most European theatre still takes place in a darkened auditorium with an illuminated stage. This suggests a strict demarcation between performers and audience, with the latter usually expected not to speak or interact openly with the stage action. The rituals associated with this form of theatre are well-understood and usually adhered to. The nature of Interactive Theatre is different in that it expects and supports audience members' engagement with the story and its characters. Consequently, the distinction between the audience and performance spaces intentionally is blurred and is not demarcated by light or physical barrier. The audience often will come to the performance with a prior knowledge of aspects of the story and some of its characters, together with hypotheses about what is going on in their lives. This technique involves the use of personal and official artefacts and written documents which orientate audience members to the story through hypotheses which are generated by two questions: 'Who are the people in this story?' and 'What's happening to them?' I term this resource a 'compound stimulus'.

\section{Authenticity}

The representation will fail in its objectives if it is judged by its target audience as unauthentic. The Interactive Theatre programme 'The Living at Hurford' dealt with the struggle of small family farms to stay in business following the foot and mouth disease outbreak in 2002 . Written by me, it was performed by community actors in a barn on a farm which had experienced the disease. When a farmer came up to me immediately after the programme ended, poked me in the chest and said 'I don't know what you know about farming boy, but how you wrote it is how it is,' I felt that the long period of research, which included talking with farmers, had produced something which he felt represented his world. Another said after another performance 'That's my life you put up there tonight.' Unless the target audience feels that the story captures its lived reality, the power of the medium to engender change and establish validation will be weakened.

\section{Attitude Change}

Research shows that Applied Drama and Theatre involvement is one of the most effective ways of altering attitudes and behaviour. A meta-analysis of existing, published research by James Catterall, for example, found that: 
Drama helps with understanding social relationships, complex issues and emotions; improves concentrated thought and story comprehension.

Research I did in the 1980s based in 35 schools across the UK showed that students positively changed their attitudes to disability as a result of experiencing a series of structured drama lessons ${ }^{i i}$. I believe that the ability of dramatic experiences to achieve this is rooted in its provision of authentic fictions, rooted in the detail of human circumstance.

\section{Targeting}

Unlike the usual theatre experience in which there is generally no way of ensuring the homogeneity of audience members, Applied Drama practitioners usually know the composition of the target audience/workshop participants. This enables its practitioners to create a dramatic experience which is most likely to engage those involved. This does not preclude variety within the target participants; in a recent project on stress in the veterinary profession, for example, audience members included student vets from each of the five study years, veterinary surgeon researchers, practising and retired vets, counsellors, therapists and those engaged in the governance of the profession. What they all shared was a knowledge - or in the case of the students, a growing awareness - of the profession and the stresses it may generate in its members.

\section{Intertextuality}

Drama's power to change attitudes is rooted in the notion of intertextuality, the dynamic relationship of stories. In this case it is the interpenetration of the performed story with the story which forms the personal identity of the individual. David Novitz $\mathrm{z}^{\mathrm{ii}}$ posits that we create the story of our self-identity through a constant process of selection and editing of the events which occur in our lives. Significant events and stories have the ability to create modifications to our perceived identity. A dramatic experience can do this too, but only if it connects strongly with 'who we are'. Although I hold that this can be achieved in workshop conditions, in the space left to me in this paper, I have chosen to focus on Interactive Theatre.

\section{How Is An Interactive Theatre Programme Researched, Developed, Delivered And Evaluated?}

To achieve an authentic performed story which is significant for the target audience, it is necessary for those making it to understand as fully as possible the issues involved. A period of research on the topic, plus experimentation with the dramatic form which wili carry the story are 
essential. It is crucial that those working on the programme have ready access to individuals who have expert knowledge of the topic - by experience and/or training. This advisory group can ensure that what is being created possesses the necessary qualities of authenticity.

The programme ${ }^{\text {iv }}$ can be developed from a script which has been created through research, or through a devising process. The latter can be open and free, but given time constraints and the need to provide some productive limitations, I usually provide a 'spine' comprising a scenario, snatches of dialogue and an overall feel of the dramatic form. Whatever the development process, it is essential that the actors are deeply involved in researching the topic. Typically, $I$ start my rehearsal/development process with two or three weeks of pooling the outcomes of research undertaken by the actors. In this way they come to understand and gain ownership of the project.

The first stage of the programme's delivery often involves the orientation of the audience to the issues and story through the use of a device I call a 'compound stimulus'. Simply, this is 'compound' in that it comprises several items, and a 'stimulus' in that it encourages story making. Much of this work involves an intimacy which can only properly be achieved by limiting the audience to around 40 in number. This optimises the opportunities for audience members to become involved in the storyline, the characters and the issues affecting them. It also makes all of the interactive work manageable. Unlike the well-made play, in which the audience meets the characters, identifies or 'feels' the problem, sees the characters wrestling with the problem before a dénouement, Interactive Theatre often stops its performed story at the crisis point. A facilitator ${ }^{v}$ then intervenes and invites audience members to understand better the problems the characters are experiencing, and to suggest ways in which they can move on the story in productive ways. I will now describe one project of this nature.

\section{On the Edge}

The 'job' here for Applied Drama was threefold. To:

- raise awareness of mental illness and specifically to increase knowledge and understanding of psychosis;

- contribute towards reducing the stigma and discrimination surrounding mental illness;

- raise awareness of available help and improve help-seeking behaviour.

The preparatory research was conducted over a period of six-months and involved the guidance of a highly committed Advisory Group, comprising those with personal experience of mental health issues, mental health professionals, an arts therapist, representatives of mental 
health charities and carers. This group also advised on the whole development process and attended and fed back on early performances. The programme was developed by Year Three undergraduate students in the Department of Drama, University of Exeter during the first semester of the 2003/4 academic year as part of a module on Applied Drama. This group toured the programme to post-16 audiences in schools, colleges and universities and to conferences for mental health professionals. Subsequently the programme was taken on by Exstream, the theatre company of which I am Artistic Director. The project received funding of $£ 148,000$ from The Wellcome Trust and other funders and was toured nationally ${ }^{\text {vi }}$. It won the Southern Region Department of Health Award for innovative practice and the National Institute of Mental Health England, National Positive Practice Award. A full and independent research report was produced on this programme's effectiveness in meeting its aims.

Prior to the start of the module and during the final stages of my pre-module meetings with the Advisory Group, I wrote a scenario and suggested scene strueture, together with extracts of dialogue. This was discussed with the Advisory Group and, after modifications, was deemed authentic. This formed the starting point for the students to begin the devising process to develop the complete performance element. Group members divided all of the other tasks between them, including preparation of the compound stimulus, data projected visual images, sound effects, music, publicity and the follow-up pack.

\section{The Storyline}

The compound stimulus contained fourteen items. It was enclosed in a shoe box. Those working with the post-16 group had been asked to explore the content and meaning of the box in the week before Exstream visited.

Items included: a letter from a school expressing disappointment at Terry Gardner's falling work standards in his AS Level studies; a photograph of a middle-teens girl, another of an older woman, and a third of a mid-teens boy with a male friend; a sports trophy for a regional event with an engraved dedication plate to Terry Gardner, a birthday card to Terry from his grandmother; a bottle of TCP ${ }^{\text {vid }}$ and cotton wool; a letter from British Olympic sprinter, Darren Campbell's agent urging Terry to keep up his training routine; a personal note from a girl; a congratulations card from 'Mum and Dad' to Terry to celebrate his good GCSE examination results at 16 . 
As outlined above, the compound stimulus was used by the teacher/lecturer in the week before Exstream visited. Before using it, the teacher announced that the box was part of a fictional story which would be performed by the theatre company next week. Participants were told that it was found under a boy's bed. Each object was extracted in turn by individual participants and its significance explored in relation to the other artefacts. This process was scheduled to last 30 minutes and at its end, the participants gained an incomplete but intriguing insight into the lives of the characters.

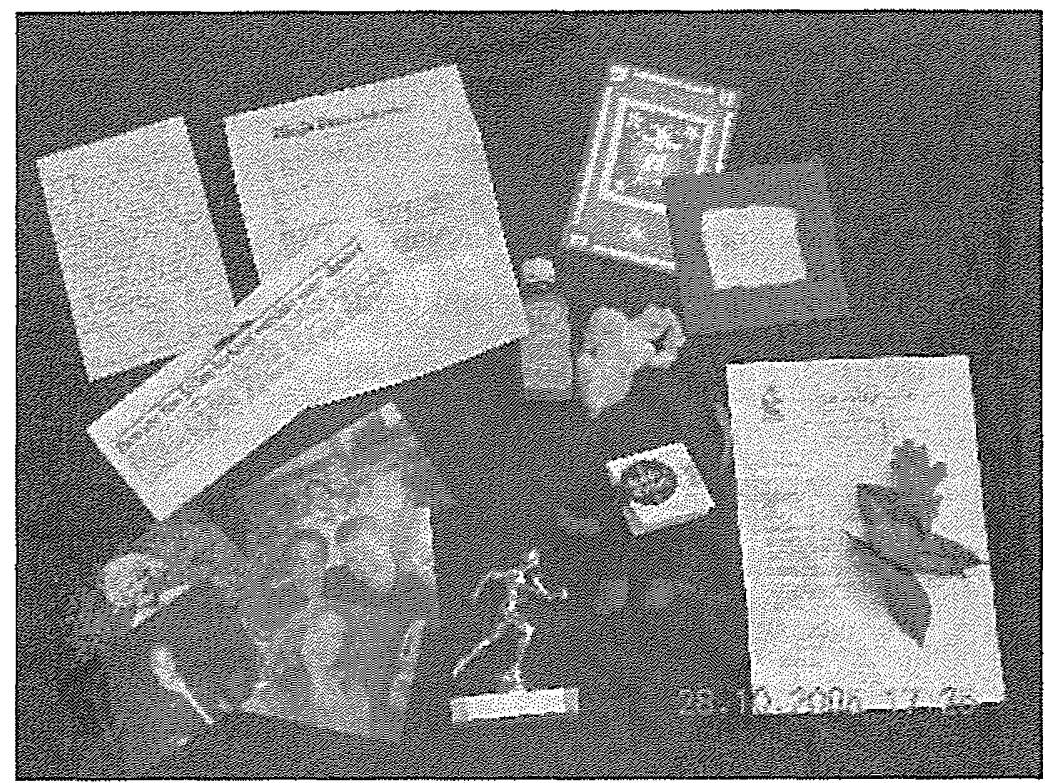

The compound stimulus

The performance element ran for 50 minutes ${ }^{\text {viii }}$. It traced the progress of Terry Gardner from being a happy boy, successful both academically and in his athletics, to the point where he experiences a first episode of psychosis. The contents of the compound stimulus were embedded in the performance element and the shoe box could be seen under his bed.

Briefly, the factors at play were his father's coaching of Terry's athletic abilities and his refusal to acknowledge that Terry had a problem; Terry's gradual slipping into a psychotic state (the TCP, which his grandmother, recently dead, used to dab on his grazes has become a magic liquid for Terry, who anoints himself with it); Terry's mother's inability to tend her son properly due to her not wishing to alienate her husband; Terry's school mates denigration of him - they use terms such as 'psycho' and 'nutter' to describe his increasingly erratic behaviour; the growing 


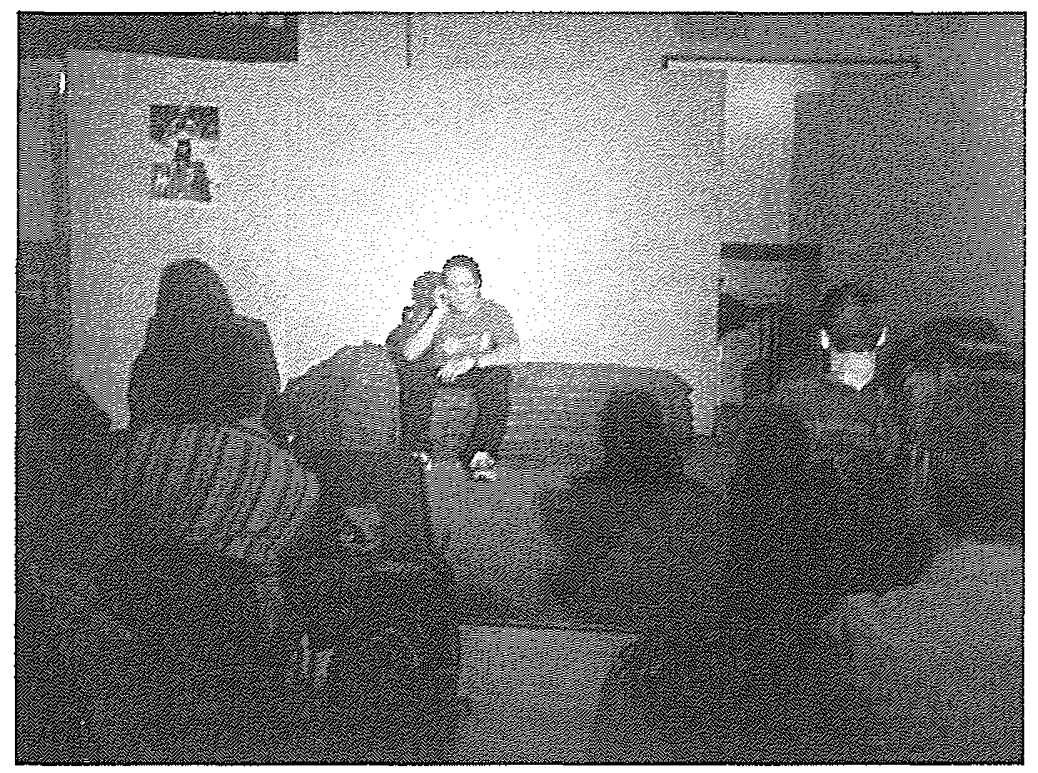

Terry telephones his dead grandmother

bewilderment of his loyal girlfriend, Sonia, who has the greatest insight into Terry's changing state and the motivation to help Terry, but does not know how to; the inability of the school to understand what was happening to Terry; Terry's phone calls to his dead grandmother.

The performance element ended at a crisis point when Terry is seeing bacteria inhabiting his bedroom, thinks the picture of Darren Campbell is glowing and pulsating and, in an attempt to protect her, shouts at and bundles Sonia out of his bedroom. She meets Terry's mother on the landing and they hold each other as his mother finally faces up to the problem.

The facilitator (for the six-month tour, this role was taken by a psychiatric nurse who was seconded by the Devon Partnership NHS Trust) stepped in and asked audience members to discuss with their neighbour what they think is going on with Terry and those around him. They were then invited to select characters to whom they wanted to talk (hotseat) in order to understand better the chosen characters' feelings and motivations. What followed differed depending on the audience group. Sometimes, audience members split into groups to work with an actor to discuss one of the character's responses within the story. At other times, audiences were asked to decide on a scene which would move on the story positively and which the actors played out. Most often, audience members were invited to give advice to the characters on how they could improve the situation. 


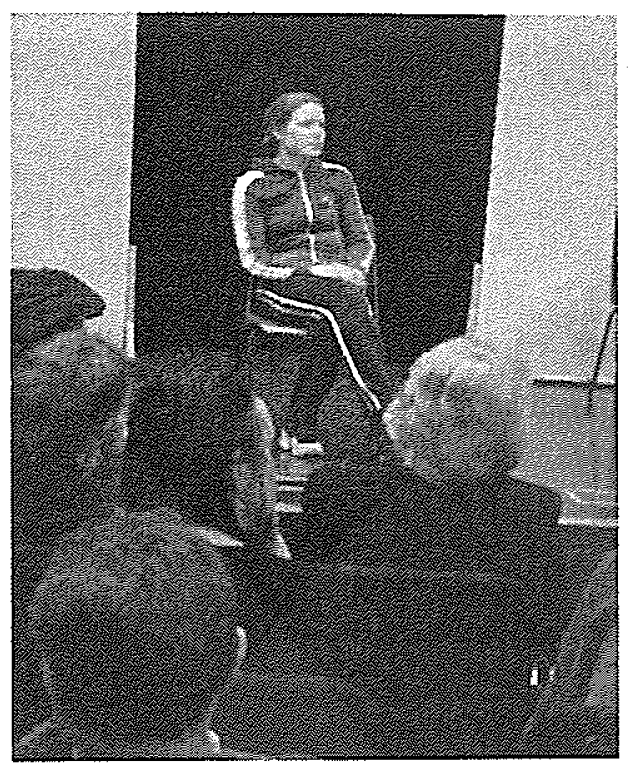

Sonia is hotseated

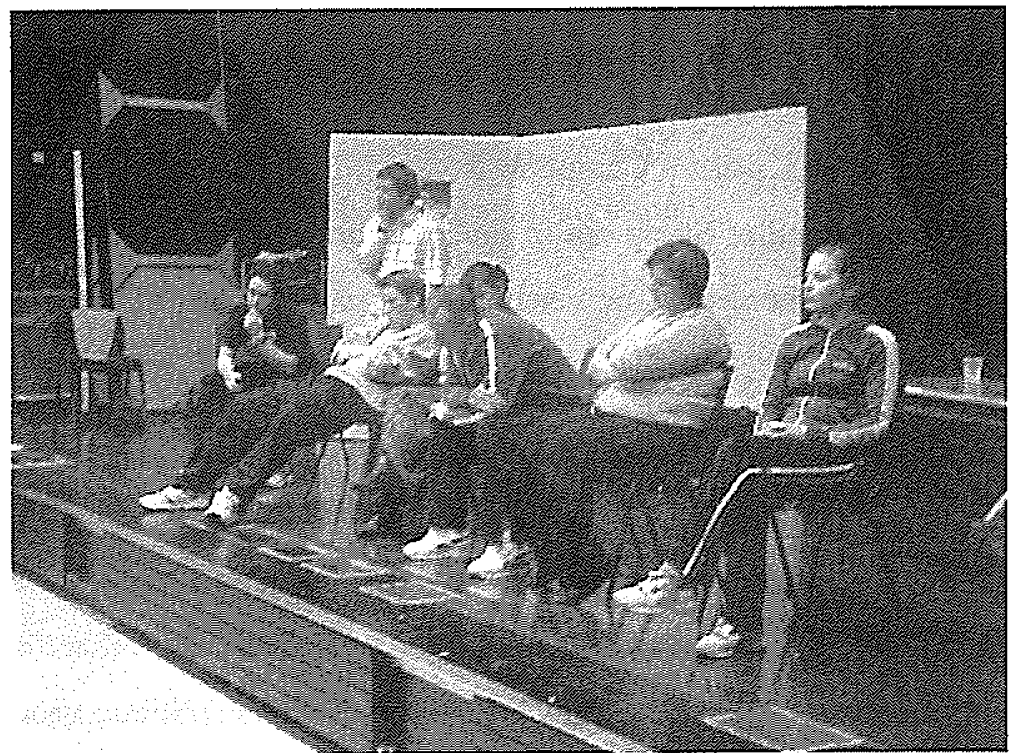

The audience gives advice to characters 
To provide some kind of closure, in the last 10 minutes of the two-hour period, the facilitator presented, with slides, the possible routes to recovery which Terry might take. Each venue was given a sophisticated follow-up pack 'Back From the Edge' which could be used at varying levels of time commitment and complexity to follow up and deepen the audience's understanding ${ }^{\mathrm{ix}}$. The person who had booked the programme contracted to use the follow-up pack in the week following Exstream's visit. Early Intervention workers ${ }^{\mathrm{x}}$ were informed of the performances and it was expected that their attendance would create enduring links between them and the personnel at each venue.

\section{The Research/evaluation ${ }^{\mathrm{xi}}$}

I believe it necessary to evaluate programmes' outcomes in relation to their aims. Such evaluation can be as simple as a post-programme questionnaire, or involve much more complex quahtative and quantitative research tools. 'On the Edge' was subject to the latter, including a six-month follow-up interview with selected participants.

\section{Key Findings ${ }^{\mathrm{xii}}$}

1. The data show increased student awareness and knowledge of psychosis following completion of the programme. Students, teachers and mental health professionals regard the subject as important and almost all respondents believed that the programme effectively raises awareness of psychosis.

2. The programme challenges stigma in a variety of different ways.

3. Students appear to be better equipped to seek help after participating in the programme.

4. On the Edge is perceived as a high-quality TIE programme by many students, teachers and mental health professionals. The major strengths of the programme are its realism, its capacity to involve the audience and the sense of safety that it gives to exploring mental ill health issues.

5. The programme deals briefly with the complex and controversial issues surrounding street drugs and understanding the psychotic experience. The small amount of feedback that comments on these two issues suggests that the overall educational message is clear and focused.

6. The programme format of the shoebox and the two-hour session worked well because it encouraged participants to become involved in the characters' lives and because it presented the information in ways that accommodated different learning styles. The play was regarded as the 
most memorable part of the programme and received substantial support as an interesting and powerful way of portraying the issues.

7. Not all schools found time for the third part of the programme despite 'contracting in' to provide this educational support.

8. The education pack 'Back from the Edge' had a mixed reception; some teachers were enthusiastic while others felt that the information was not easy to access. Lack of available time to read and reflect on the materials contributed to this reaction.

\section{Conclusion}

This was a complex project which set itself ambitious goals. The research outcomes show that many of these were achieved and there is strong evidence that this Interactive Theatre programme is an effective way of dealing with a very sensitive topic. During the tour, twelve audience members presented themselves to the psychiatric nurse or to the local EI workers to seek help. It is likely that many other consultations took place subsequent to the company's visits, facilitated by information provided to each audience member at the end of the two-hour visit.

I claim that Applied Drama of this nature is an essential element in supporting well-being, especially through its ability to deliver powerful and authentic portrayals of issues which are difficult to root in discussion which directly uses participants' experience as illustrative material.

(This article is based on one published in: Dramatherapy and Social Theatre (2008), Sue Jennings (Ed) London: Routledge.)

\footnotetext{
'See Taskforce on Underage Alcohol Misuse, Kate Fox (1997), London: The Portman Group, p.27.

ii See my article in Somers, J., (Ed), (1996) 'The Nature of Learning in Drama in Education', in Drama and Theatre in Education: contemporary research, Captus Press, North York, Canada, pp. 107-120

iii Novitz, D. (1997). Art, Narrative and Human Nature' in Hinchman L. \& Hinchman, S. (Eds.) Memory, Identity, Community, New York, State University of New York.

iv I use the term 'programme because the terms 'production', 'play', performance or 'show' do not adequately capture the range of theatrical, artistic, sociological and pedagogic structures which such work entails. I refer to the performed story (just one of the elements) as 'the performance element.'

${ }^{\checkmark}$ A facilitator acts as a bridge between the audience and the story. They can signal and support ways in which audience members interact with the characters.

${ }^{\text {vi }}$ The company undertook a national tour between October 2004 and March 2005, performing to 123 audiences, of which 79 were in 54 schools, colleges and universities where the target audience age was between 14 and 22 . Fortyfour were performances for teachers and mental health professionals where the programme was used as a part of continuing professional development (CPD) and or as a conference presentation to support the new Early Intervention (EI) in Psychosis services that were being introduced in England at the time.

vii TCP is an antiseptic lotion commonly used in households for minor wounds.

viii Excluding the compound stimulus and the follow-up, the whole programme required two hours.

ix This was prepared by Dr Glenn Roberts, the consultant psychiatrist who assisted with the development of the programme. The pack was subsequently adopted by NIMHE for national use.
} 
${ }^{x}$ EI workers are being appointed across England. Swedish research shows that the sooner intervention takes place, the more rapid the recovery of the patient.

${ }^{x i}$ The research used both quantitative and qualitative methods:

- pre- and post-performance questionnaires for students at schools, colleges and universities (from 29 institutions; not all completed both parts of this research).

- evaluation forms from those attending non-student performances $(\mathrm{N}=474)$.

- interviews with students, teachers and those attending non-student performances (72 interviews with 133 students, teachers and mental health professionals).

- cast research diaries which recorded the number and gender balance of people in the audience, the type of questions asked in the hotseating and any striking or unusual occurrences during the two-hour session.

xii The Key Findings have been extracted in abbreviated form from the Executive summary contained in the final evaluation report produced by Dr Rowena Passy (principal researcher and author) and Dr Jos Dawe. The full report will be available on the Exstream website in 2007. 